\title{
الترجمة ووضع تعليمها بإندونيسيا
}

\section{ليلي فطرياني}

\begin{abstract}
Abstrak
Gerakan penerjemahan telah tumbuh dan berkembang pesat sejak masa Abbasiyah. Dibuktikan dengan adanya penerjemahan buku-buku berbahasa Yunani, Persia dan Romawi ke dalam bahasa Arab. Sehingga terjemah memiliki peranan yang sangat penting dalam perkembangan peradaban Islam.

Dalam pembelajaran Bahasa Arab untuk non Arab, terjemah telah menjadi salah satu metode tertua, yakni metode gramatikal dan terjemah dalam pembelajaran Bahasa Arab di Indonesia. Metode ini banyak digunakan di pondok pesantren, madrasah maupun perguruan tinggi.

Pembelajaran terjemah di perguruan tinggi, sebagai contoh di jurusan Bahasa dan Sastra Arab UIN Maulana Malik Ibrahim Malang ini memiliki model serta tahapan tersendiri yang tergambar dalam Satuan Ajar Perkuliahan (SAP). Selain hal tersebut, beragam permasalahan di bidang terjemah juga sering dihadapi mahasiswa, antara lain disebabkan kurangnya pemahaman yang baik dari bahasa sumber untuk diterjemahkan ke dalam bahasa sasaran.
\end{abstract}

Kata kunci: Penerjemahan Bahasa Arab, Indonesia

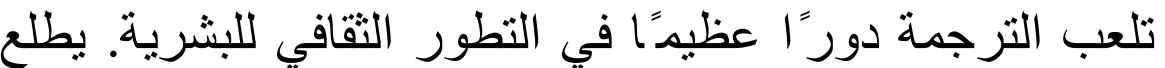

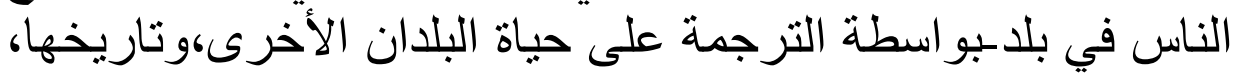

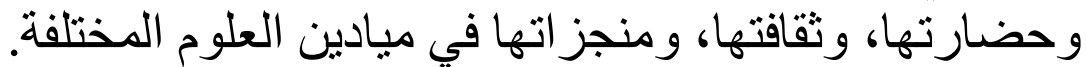

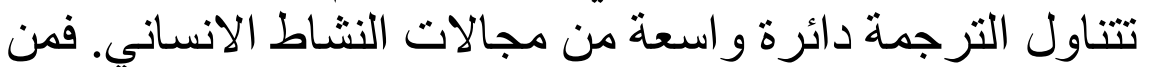

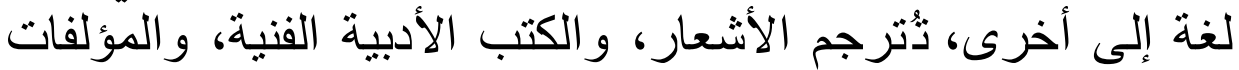

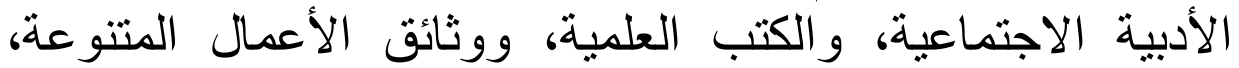

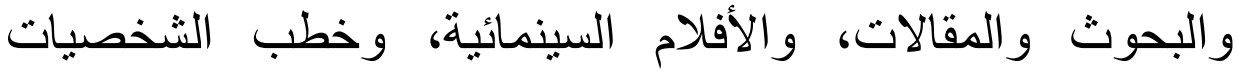

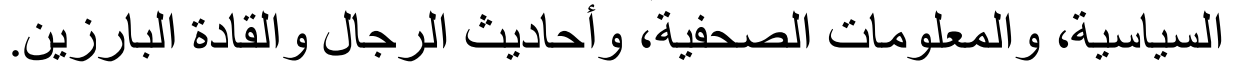

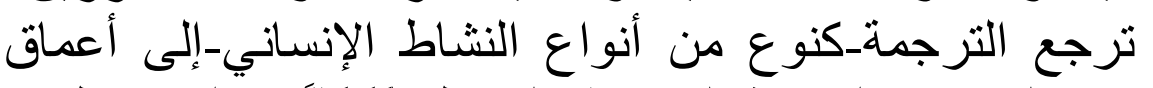

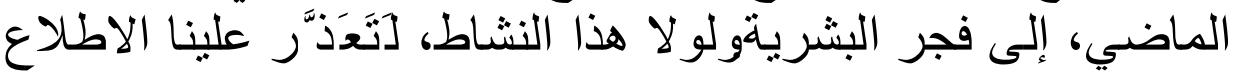
على الثقافات المختلفة، كالثقافة الفارسية، والثقافة لافة الثندية، والثة والثقافة اليونانية. 


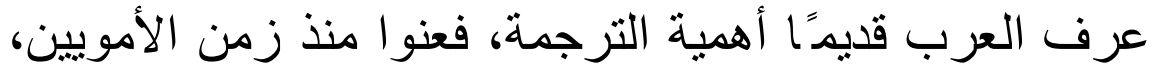

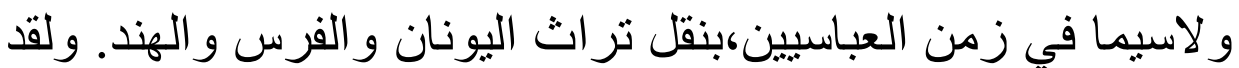

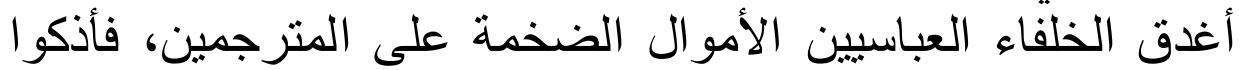

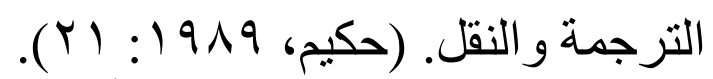

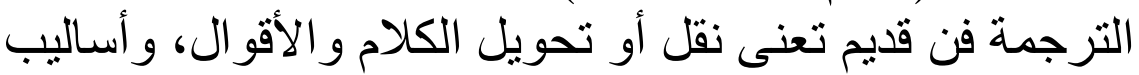

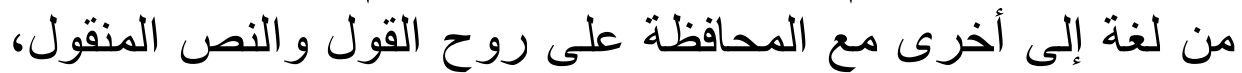

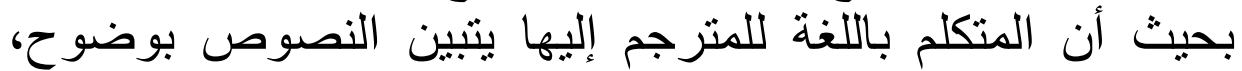

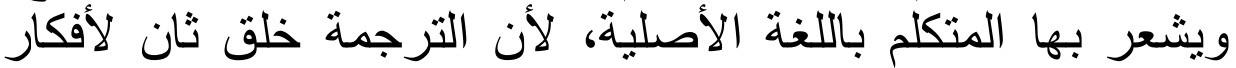

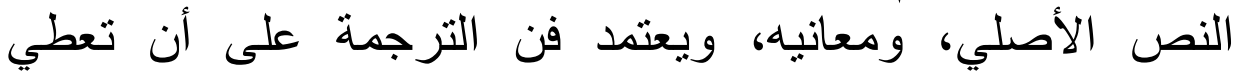

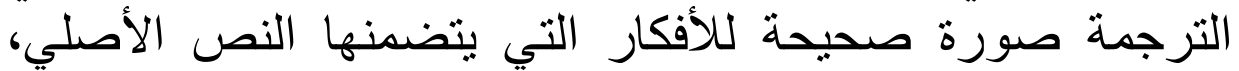

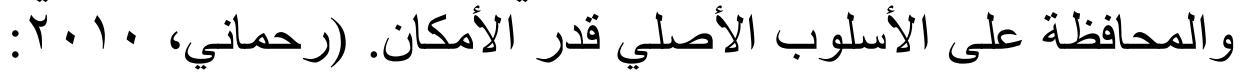
. (r) - (r)

وبناء على ذللك، كانت الترجمة لها دور كبير ومهم في بناء

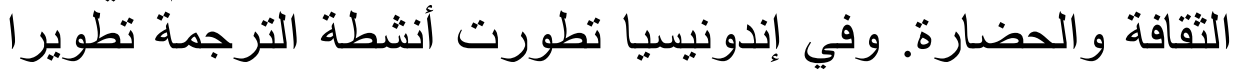

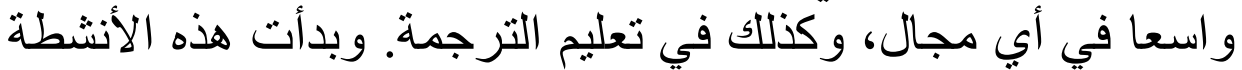

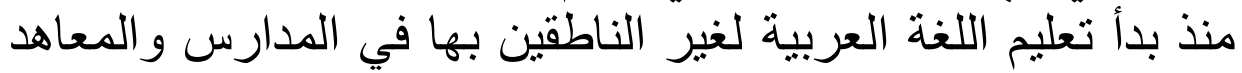
حيث تسنعمل طريقة القواعد و الترجمة في مطالعة كتب النئ التراث

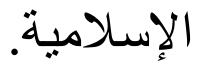

و هذه المقالة البسيطة سوف تبحث عن معاني الترجمة، أنواع وشروط وطرائق الترجمة ووضع تعليم الترجمة بإندونيسيا و وموضوعها.

أ) معاني الترجمة في اللغة والإصطلاح

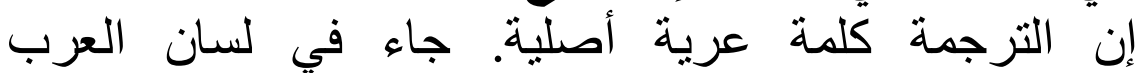

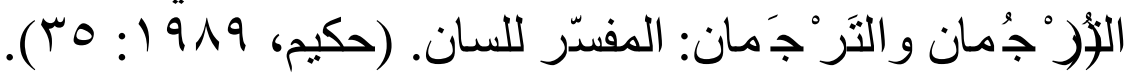

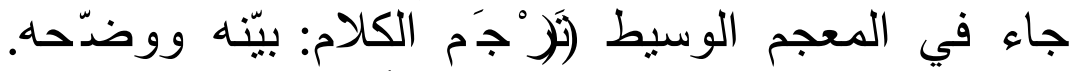

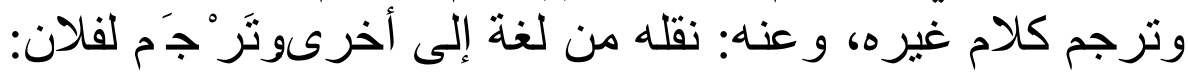

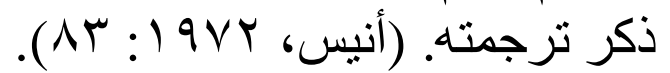
تستعمل كلمة ((الترجمة)) لتدل على أحد الأنو اع التالية: 
ا. الترجمة بصفتها العملية الفعلية لفك رموز النص في اللغة الأصلية وترميز النص في اللغة الهدف.

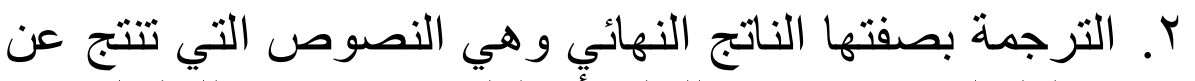

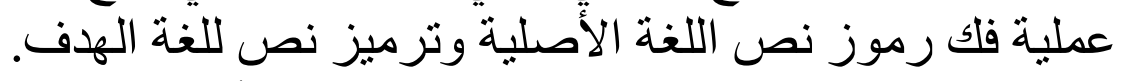

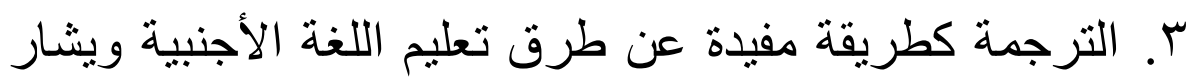

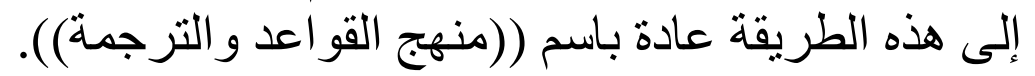

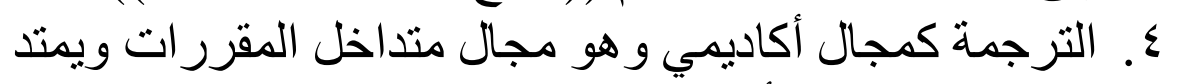

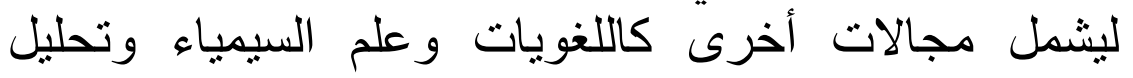
النصوص وعلم اللغة الإجتماعي وعلم المنطق ولات وعلم اللغة

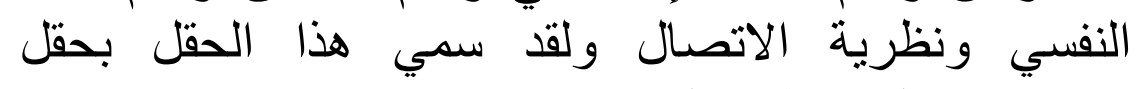

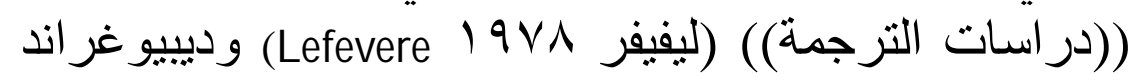

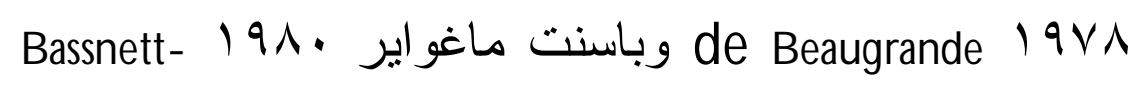
كما يدعو (بع (بG aire

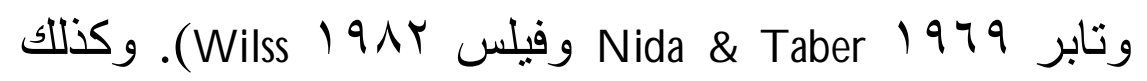

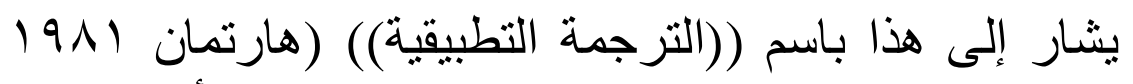
(H art-mann

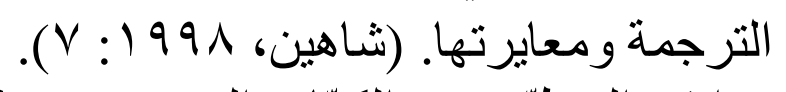

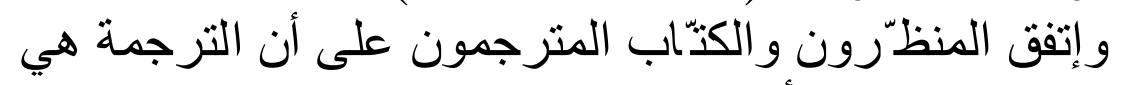

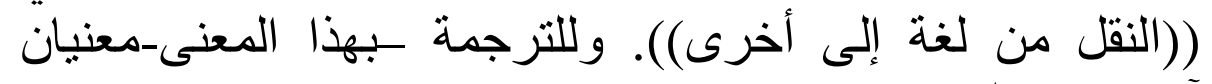

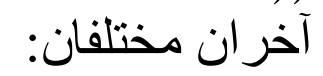
المعنى الأول ((الترجمة كنتيجة لعملية محددة))، أي أنها

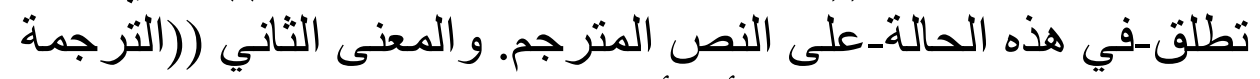

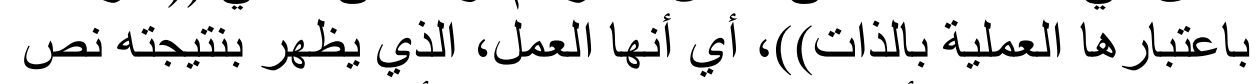

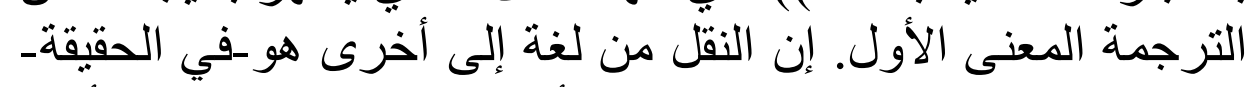

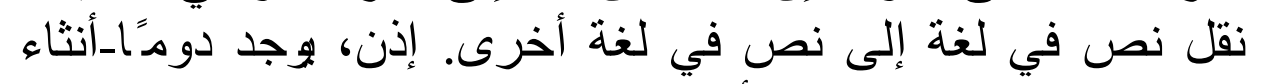

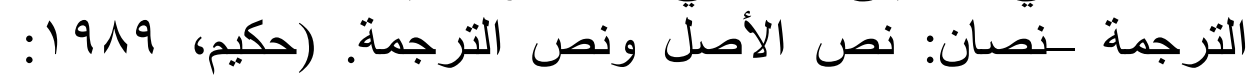
. ( 


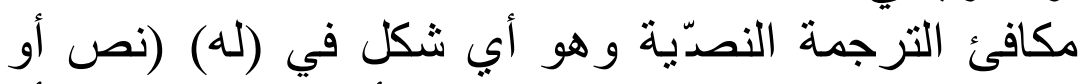

ب) - (بكافؤ الترجمي

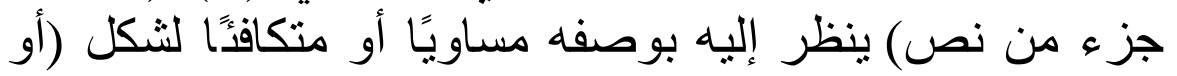

$$
\text { نص" أو جزء مننص نصّ ) في (لم). }
$$

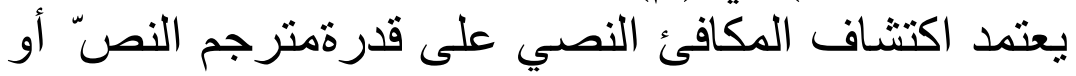

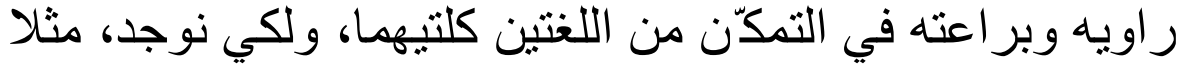

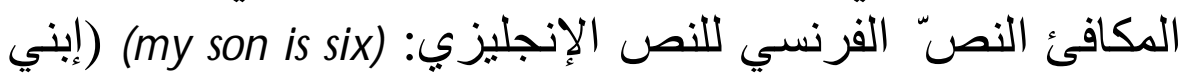

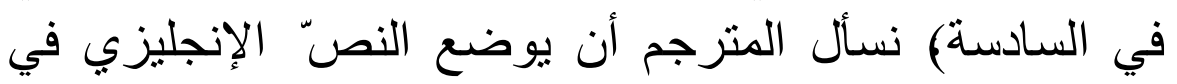

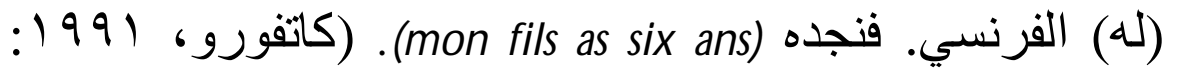

و الثروط الضرورية التي يمكن من خلالها لمفردة في (له) فئ)

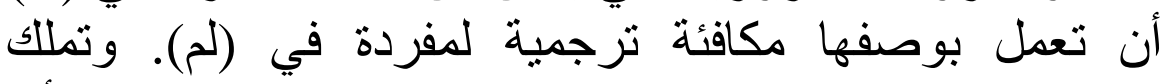
مفردات (لم) و (له) المعنة نفسه بالمعنى اللغوي الدقيق، إلا أنها

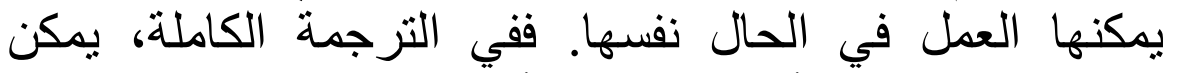

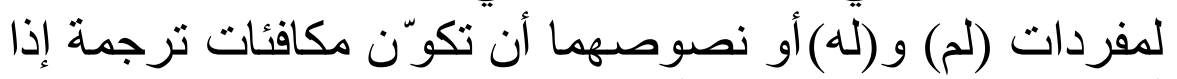

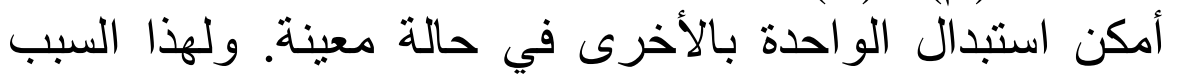

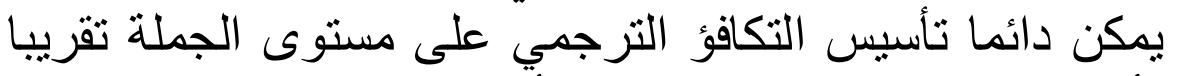

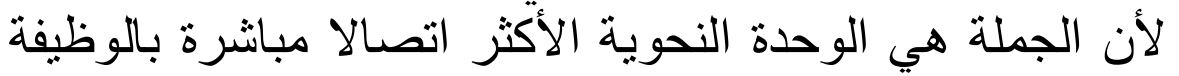

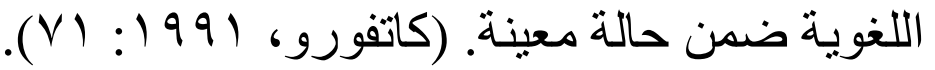

$$
\begin{aligned}
& \text { ج) أنواع الترجمة }
\end{aligned}
$$

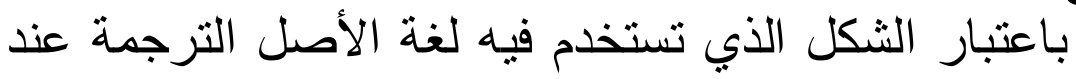

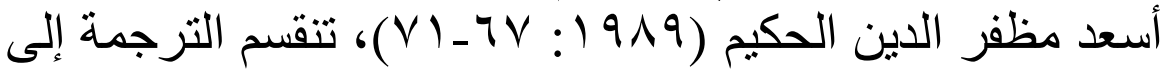

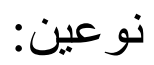

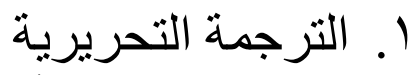

التحريرية أو الترجمة التحريرية للنص التحريري

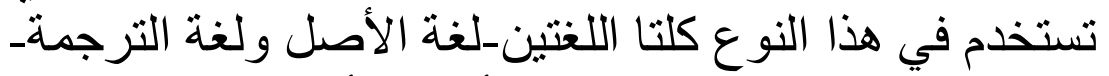

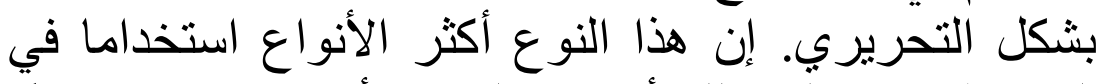

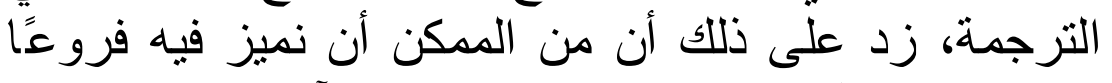

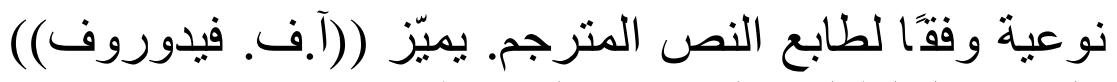
الفروع التالية لهذا النوع من الترجمة: 
(1) ترجمة النصوص الصحفية الاعلامية و الوثائقية.

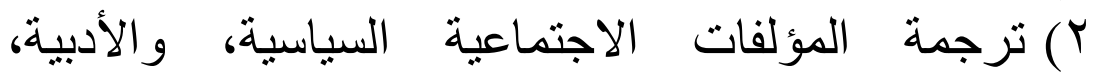
و الاجتماعية، وكلمات الخطباء. ب) ب ترجمة المؤلفات الفنية.

ظهرت الترجمة التحريرية على أثر اختراع الكتابة

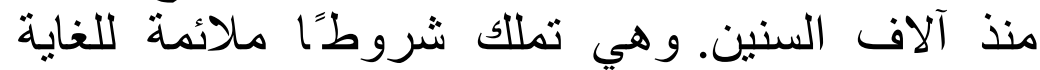

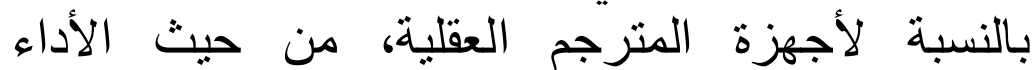

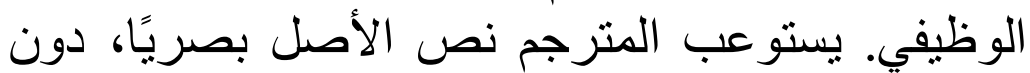

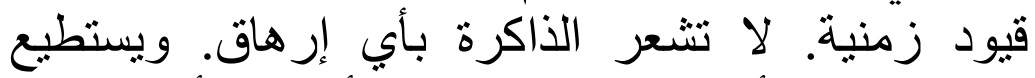

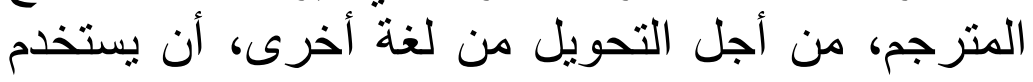

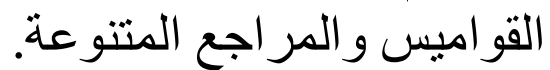

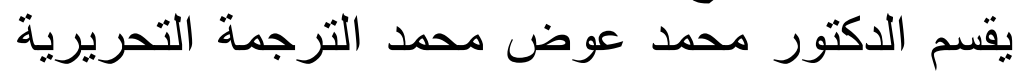

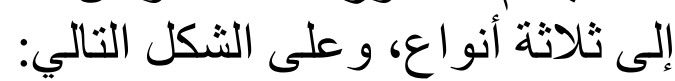

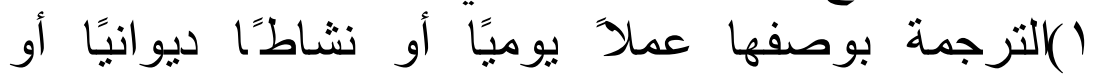
مصلحيًا، يجري كل بحكم العمل المطرد الرتيب، فئا فئاك

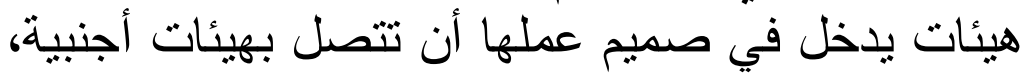

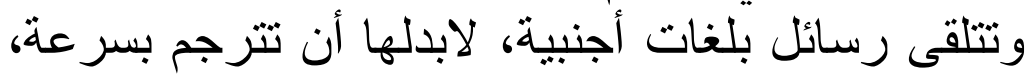

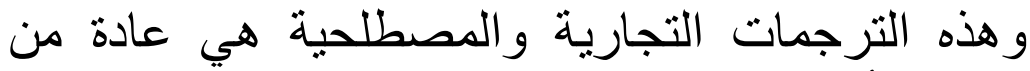

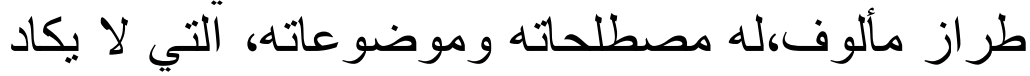

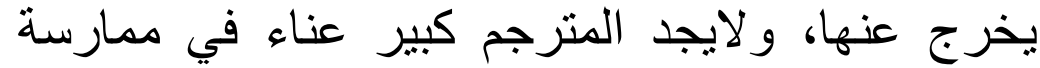
عمله و إنجازه بسر عة ولايجة تكاد تكون آلية.

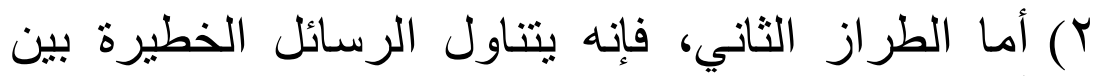

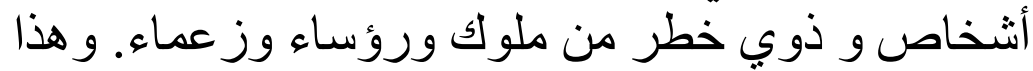
الطر از و إن كان قليلا في وقتنا هذا، فإنها في الحقيقة من ون أقدم مظاهر الترجمة التحريرية.

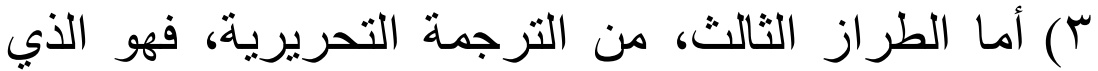

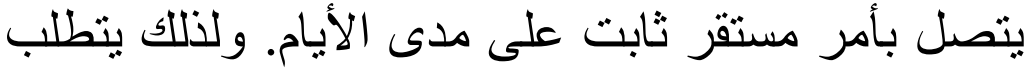

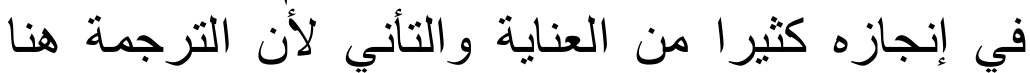

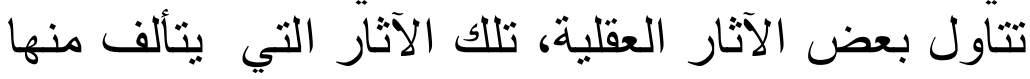
التراث الثقافي لكل جيل من الناس. 


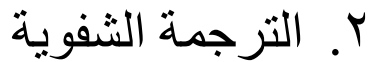

الثفهية أو الترجمة الثفوية للنص الثشفي: تستخدم في هذا

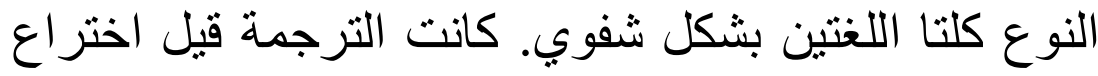

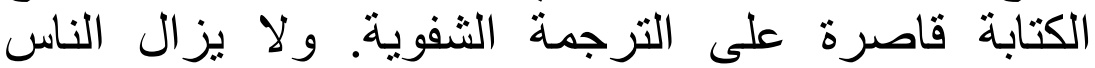

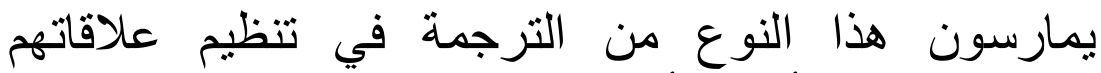

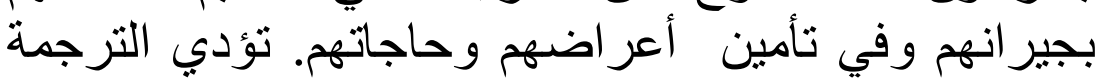
الثنفوية وظيفة هامة في المعاملات و المنظمات الدولية الدية وفي

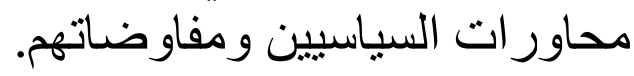

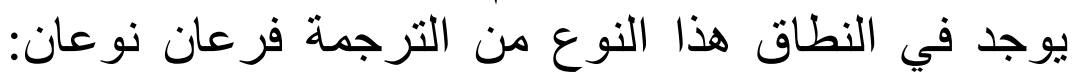
الترجمة المتتابعة والترجمة التزام امنية (الفورية).

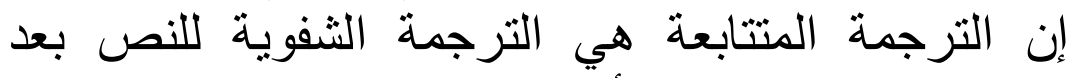

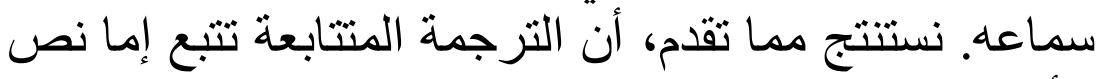

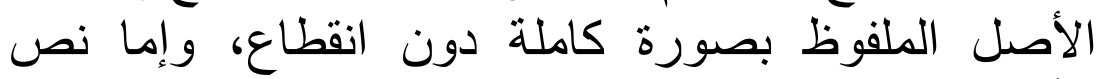

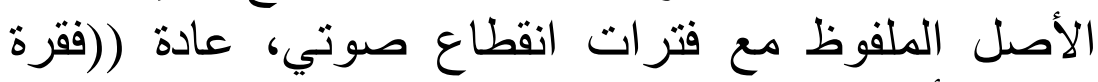

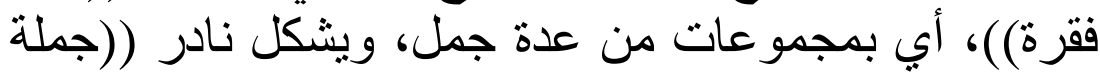
جملة)) أبي بجمل مستقلة مع التوقف بعد بعد كل جملة. إن الترجمة التزامنية (الفورية) هي التنفيذ الآني لعمليات استيعاب النص الأصلي سمعيا والصياغة الثنفوية للترجمة.

\section{د) شروط الترجمة}

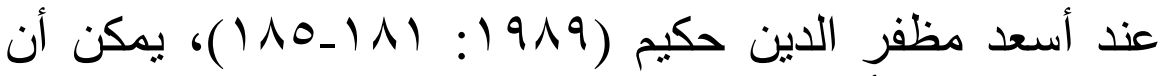
نوجز الثروط الأساسية في خمس نقاط:

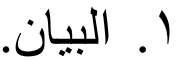

إن النص هو المصدر الأساسي للمعلومات، التي تمكّن

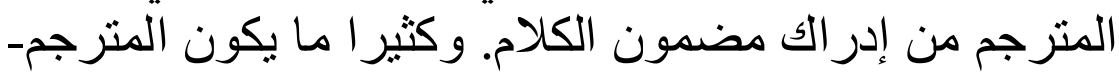

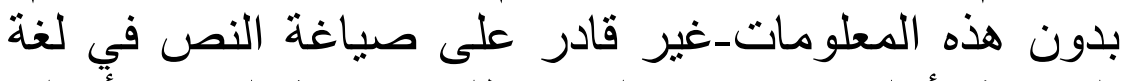
الترجمة بأسلوب فصيح وبليغ. تتطلب ترجمة النصات النص الأصلي

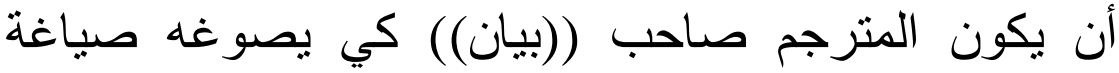

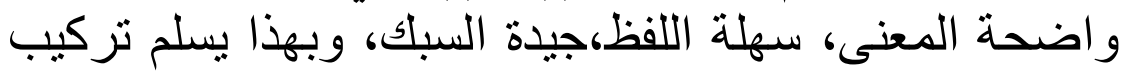

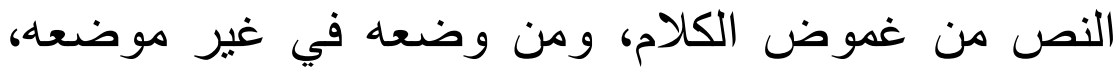
ويخلو من تنتفر الحروف، ومخالفة القياس اللغوي، وغرابر هوضية 
الاستعمال، و الكراهة في السمع، ويخلو أيضا من تنافر الألفاظ، وضعف التألتيف، و التعقيد. r. معرفة اللغتين: المنقول منها و المنقول إليها.

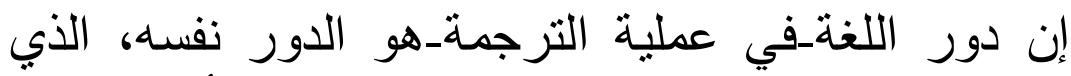
تلعبه على الدوائم في حياة المجتمع، باعتبار ها أهم واسطة

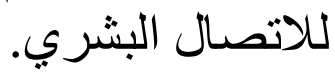

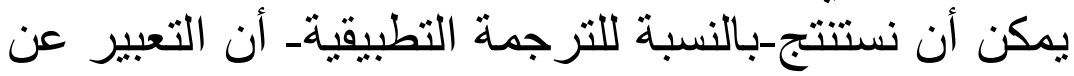

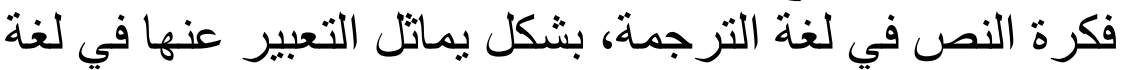
الأصل، أمر تستدعيه أمانة الترجمة الدقيقة، وإلا فإن إن الفكرة

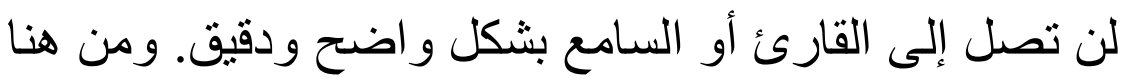

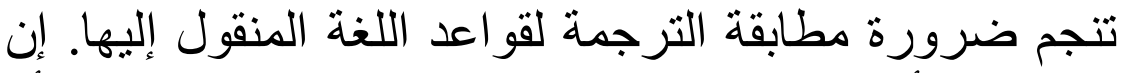
هذا شرط أساسي لوضوح الترجمة، وبالتالي لفهم القارئ أو التئ إن ضعف المترجم في اللغة التي ينقل إليها يؤدي إلى إلى إلى

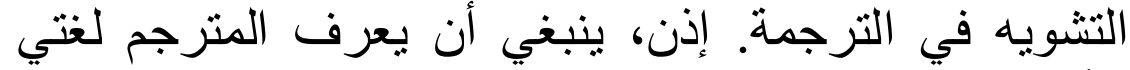
الأصل و الترجمة معرفة عميقة، تثنمل كافة الجوانب التب اللغوية:

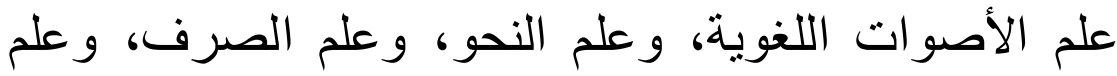

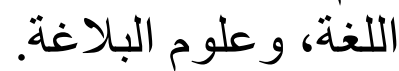
r. معرفة الموضوم ع المنقول.

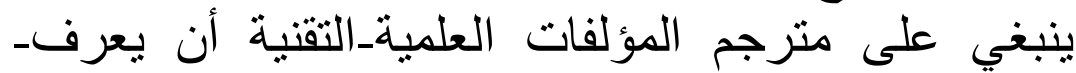

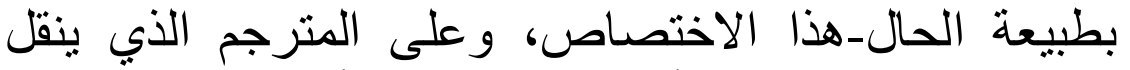

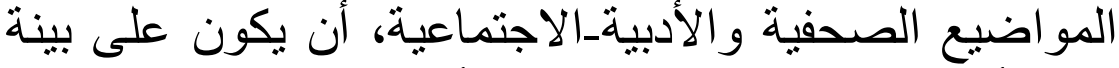

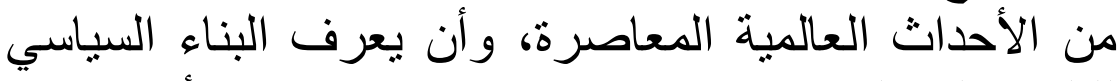

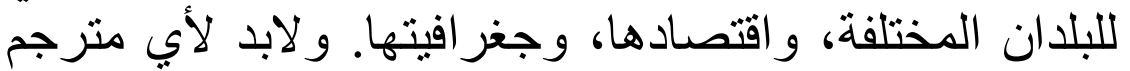

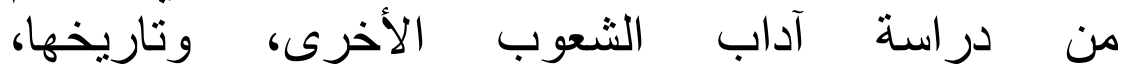

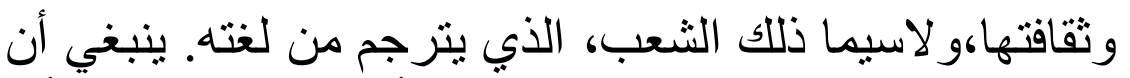

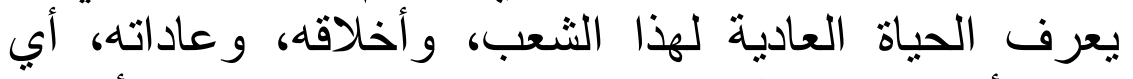

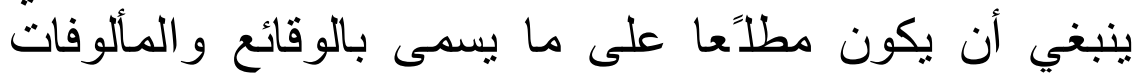
الثقافية و التاريخية. 
ع. ثقافة عامة.

إن الثقافة ضرورة لاغنى عنها لأي إنسان، ولاسيما

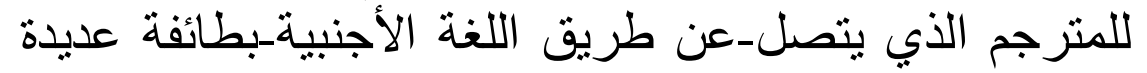

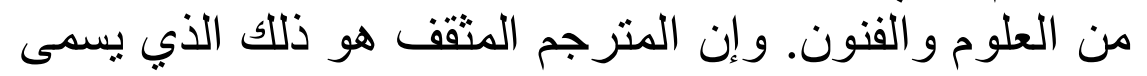
إلى الـعارف، ويعلّم نفسه مدة حياته.

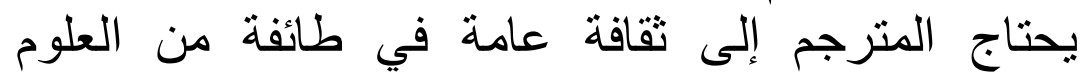

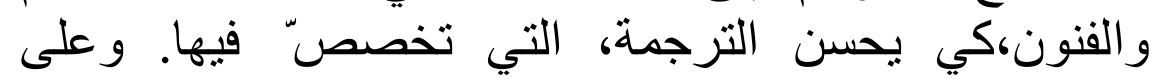

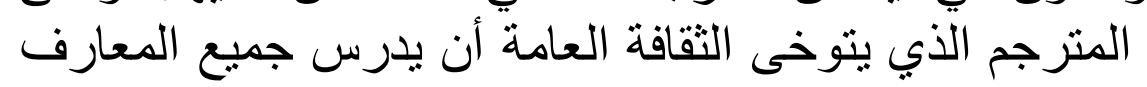

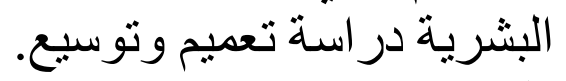

إن معرفة لغة أجنبية لا تصنع مترجما ناجحا، إذ لا نت إنت ه) أهمية المترجم

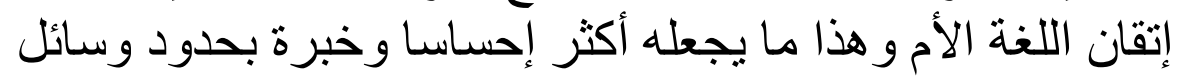

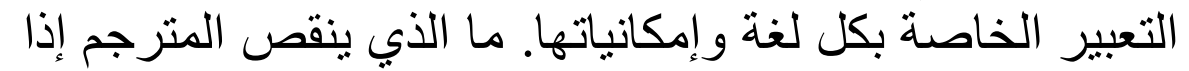

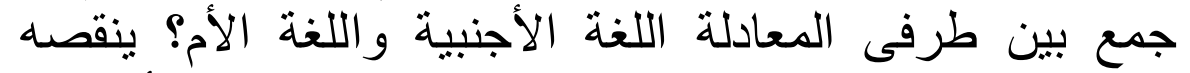

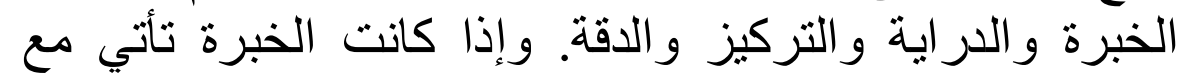

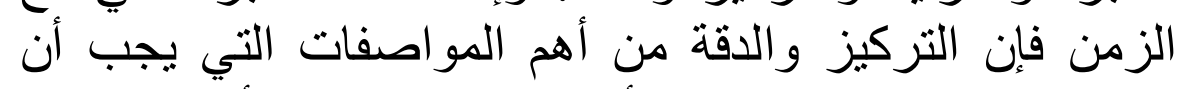

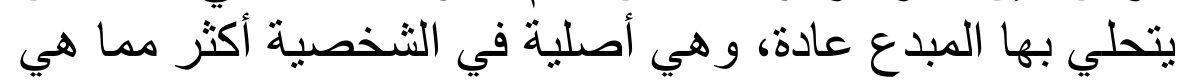

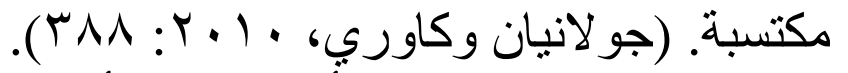

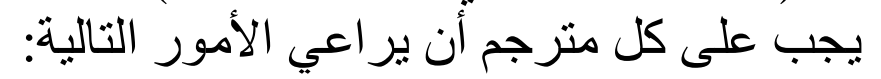

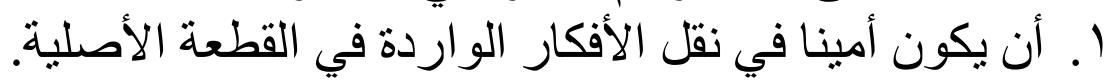

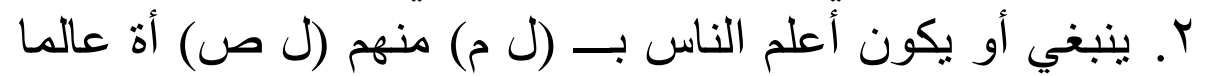

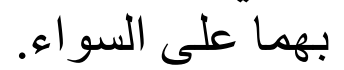
r. بينغي أن يكون متخصصا في الموضو اءوع الذي يترجم فيه. ع. ـ وأن يظهر القطعة المترجم بنفس روح القطعة الأصلية. 0. و أن يفهم شخصية المؤلف تمام الفهر.

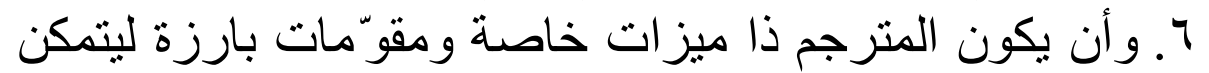

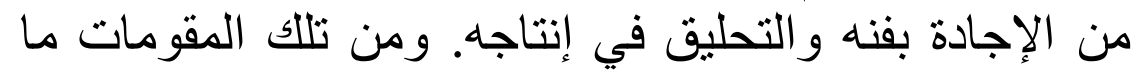
يلي: 
() لإلمام التام باللغتين، إذ من السخافة (الغير المعقول) أن

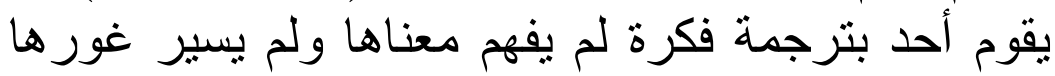
ولم يقف على ما فيه من جمال المعنى و والمبنى. لمني. r) أن يكون المترجم متمكنا من اللغتين و إلا وقع في الماني

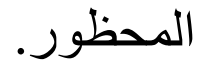

r) لابد للمترجم أن يكون ذا اختصاص في الموضوع الذي لئي

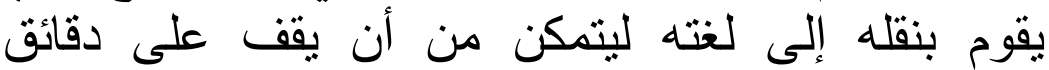

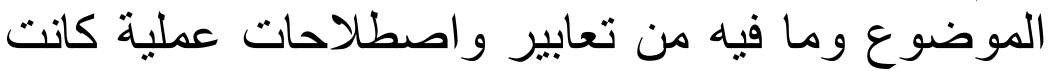

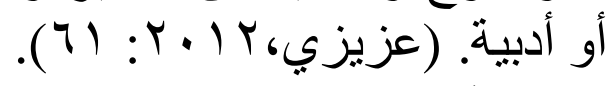
و)طر ائق الترجمة أنية

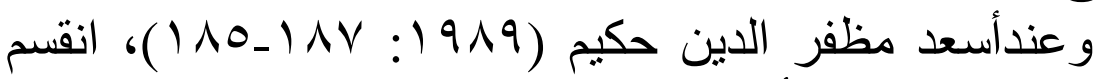
طر ائق الترجمة إلى أربع طر ائق: ا. الترجمة الحرفية. (Literal T raslation)

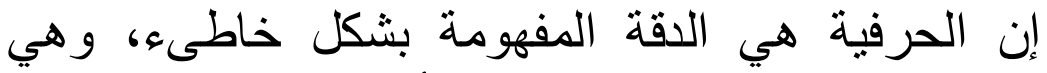

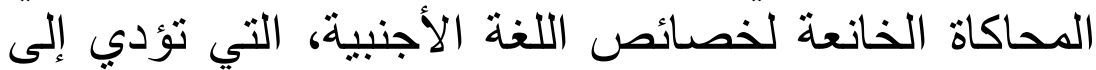

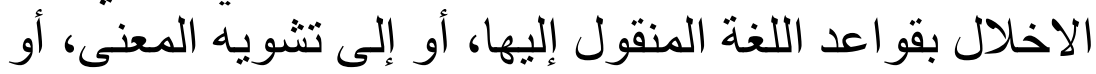

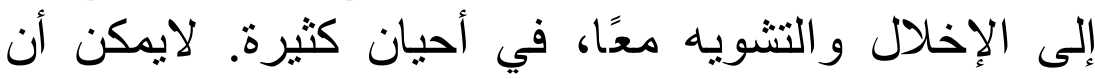

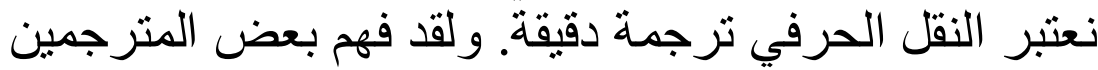

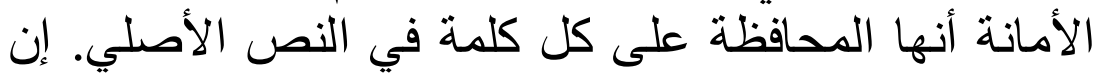
الحرفية المعجمية، والحرفية القواعدية، الحية، تؤديان إلى الإلى النقل

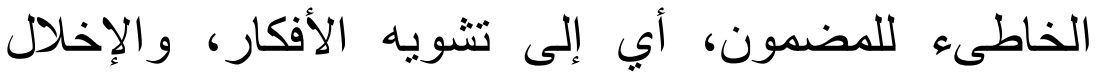
بقو اعد لغة الترجمة. حكيم (1919 (1) (1) ).

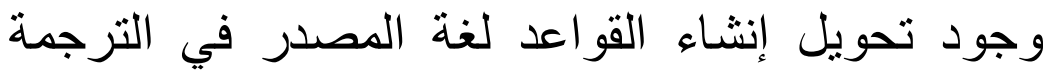

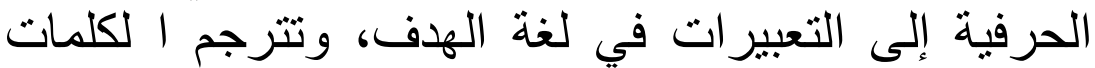

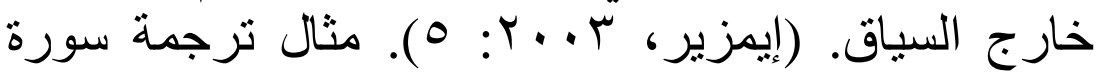
الإسر اء: ج ج عند يس: (اليزير،

29. dan janganlah kamu jadikan tanganmu terbelenggu pada lehermu dan janganlah kamu terlalu mengulurkannya[852] karena itu kamu menjadi tercela dan menyesal.

[852] Maksudnya: jangan kamu terlalu kikir, dan jangan pula terlalu Pemurah. 
r. الترجمة الحرة (لFree Translation)

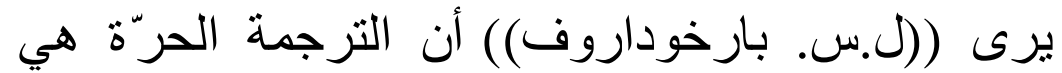

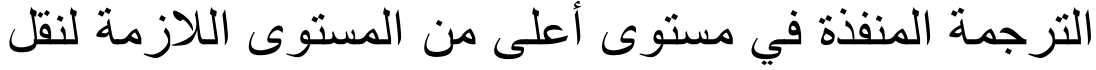

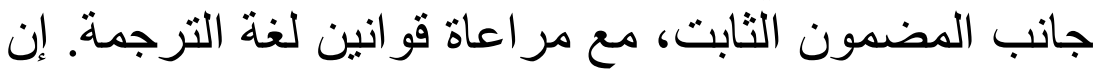

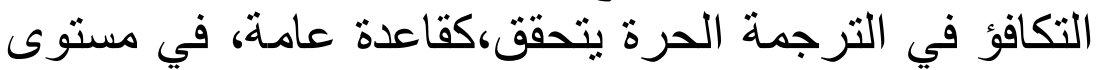

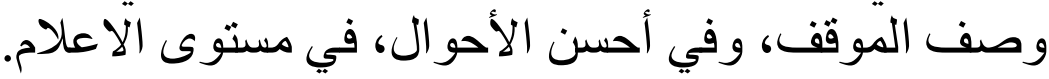
هذه الطريقة تهتم إلى المحتوى ولا لالى تهنم إلى اللى اللغة

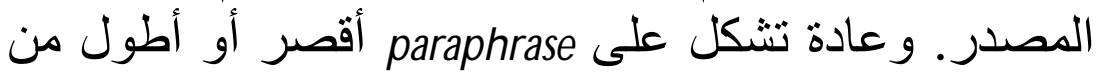
النصوص الأصلية وتستعمل هذا الثنكل في مجال الصحافي.

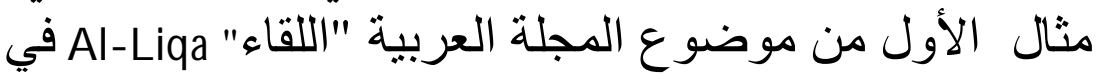

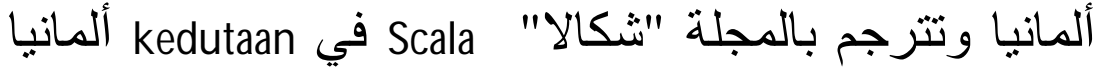
في إندونيسيا. ومثال الثاني الخبر السياسي من الصحيفة.

\begin{tabular}{|c|c|c|}
\hline لغة الهرف & لغة المصدر & رقق \\
\hline $\begin{array}{l}\text { Pembaharuan W ilayah } \\
\text { Pemerintahan Ibukota Baru } \\
\text { (Lama) Jerman-Berlin }\end{array}$ & 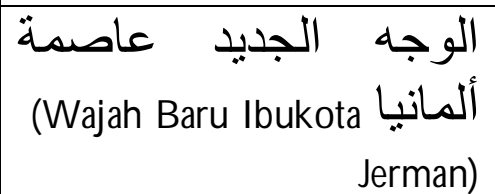 & .1 \\
\hline $\begin{array}{l}\text { R akyat Palestina menolak usul } \\
\text { A merika yang bertujuan } \\
\text { mengaktifkan kembali } \\
\text { perundingan damai dengan } \\
\text { Israel melalui ide pembagian } \\
\text { tempat suci Kristen dan Islam di } \\
\text { kotaY erusalem lama. }\end{array}$ & 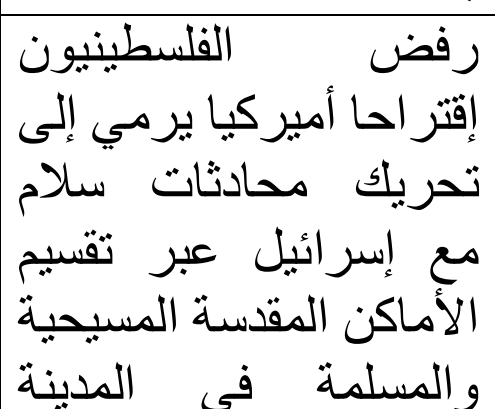 &.$r$ \\
\hline & & \\
\hline
\end{tabular}

بـ الترجمة المعنوية (Semantic T ranslation)

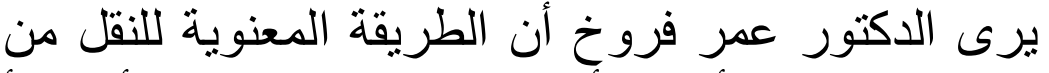

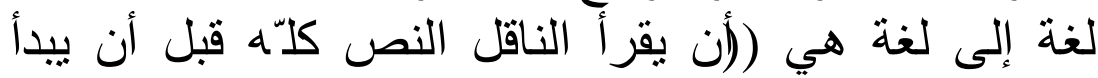

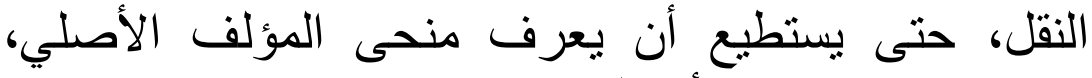

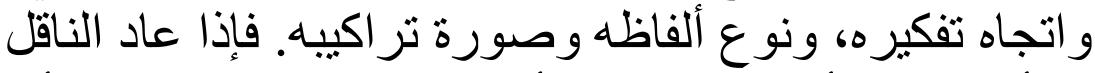
ليبدأ عمله، قرأ جملة تامة، ثم أدار ها في ذهنه حتى يوقن أنها أنها 
قد فهم معناها ومرماها. بعدئذ يختار لها الألفاظ التي تعبر

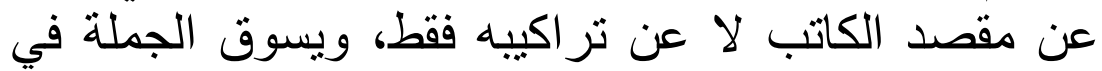

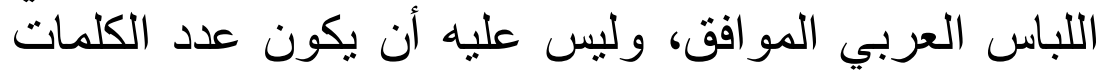
في جملته مثل عددها في النص الأصلي أو أكثر أو أقل.

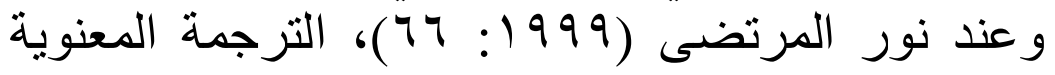

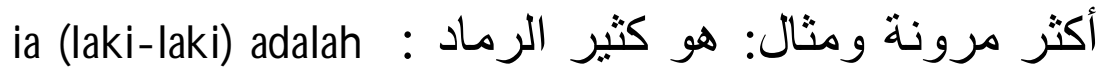
orang dermaw an. ع. ـ الترجمة الممانلة

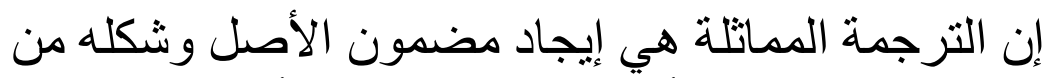

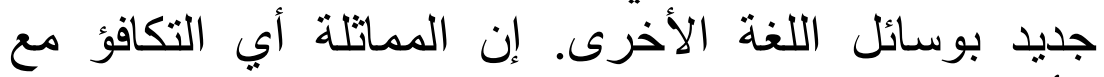

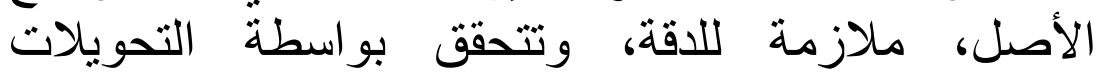
القو اعدية، و المعجمية، و البلاغية، التي تنشئ التأثنير التكافئ.

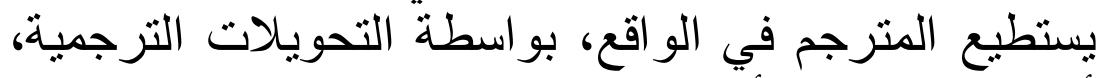

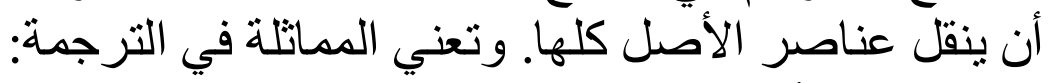

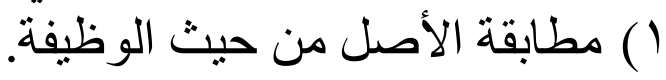

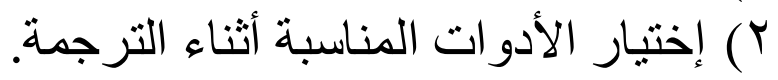

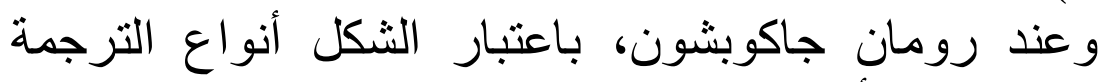

$$
\text { تتكون على ثلاث أنواع: }
$$

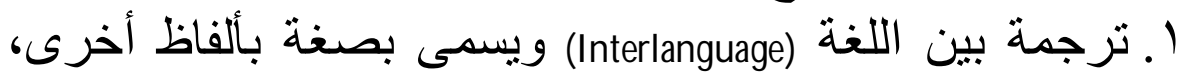

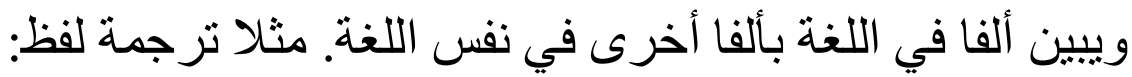

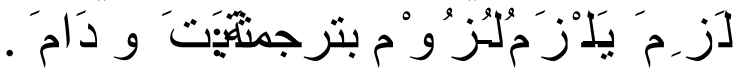

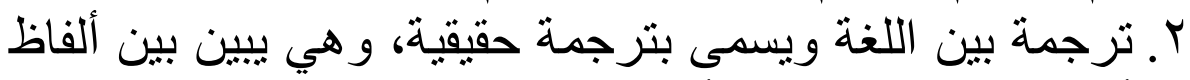

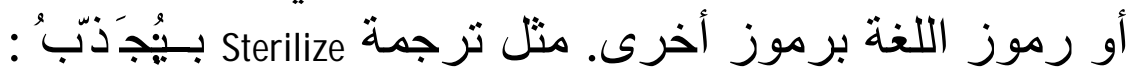

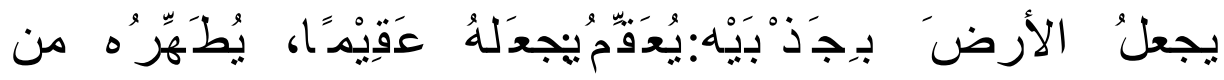

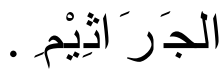

ץ.ترجمة بين الرموز (Transferensi)، هي ترجمة الرمة الرمز اللغة

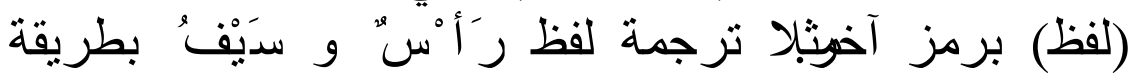

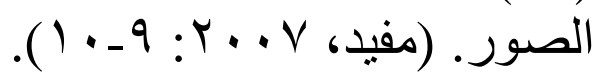

$\leqslant \wedge$ 


\section{ز)وضعية تعليم الترجمة في إندون يسيا}

عرفنا بأن الترجمة هي نقل التوني الرسالة من اللغة إلى اللغة

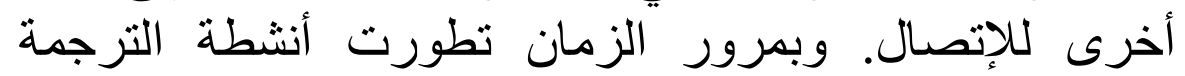

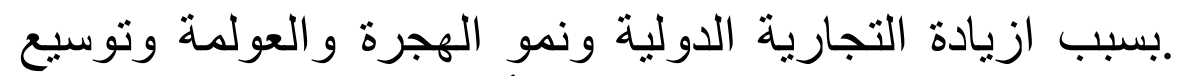

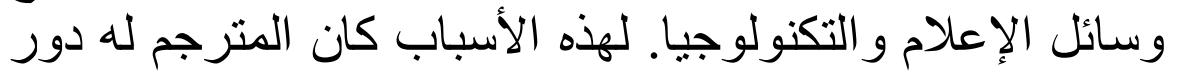

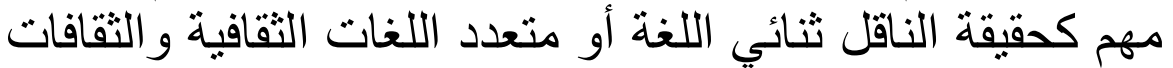

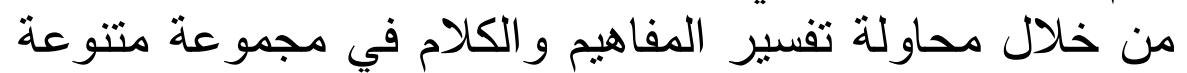
من النص في الواقع، وجيدة ودقيقة قدر الإمكان. (إيمزير،

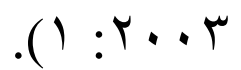

وعند يورياويناتا (r (1919 (191 في إمزير)، برى بأن عملية

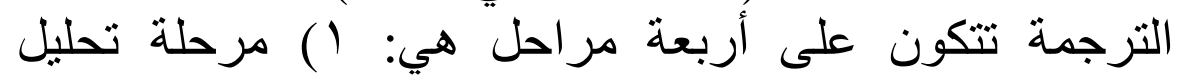

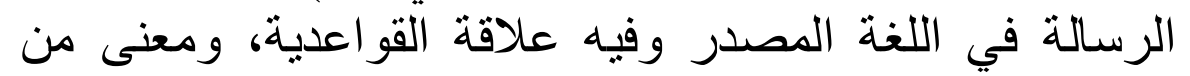

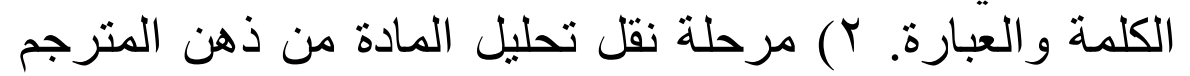

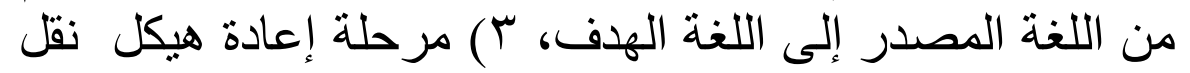

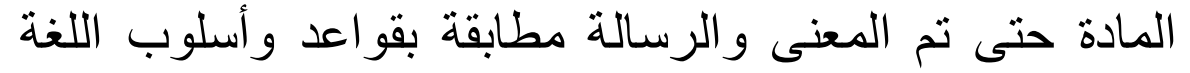
الهدف، و ع ) تقويم وتتقيح نتيجة الترجمة في اللغة الهدف.

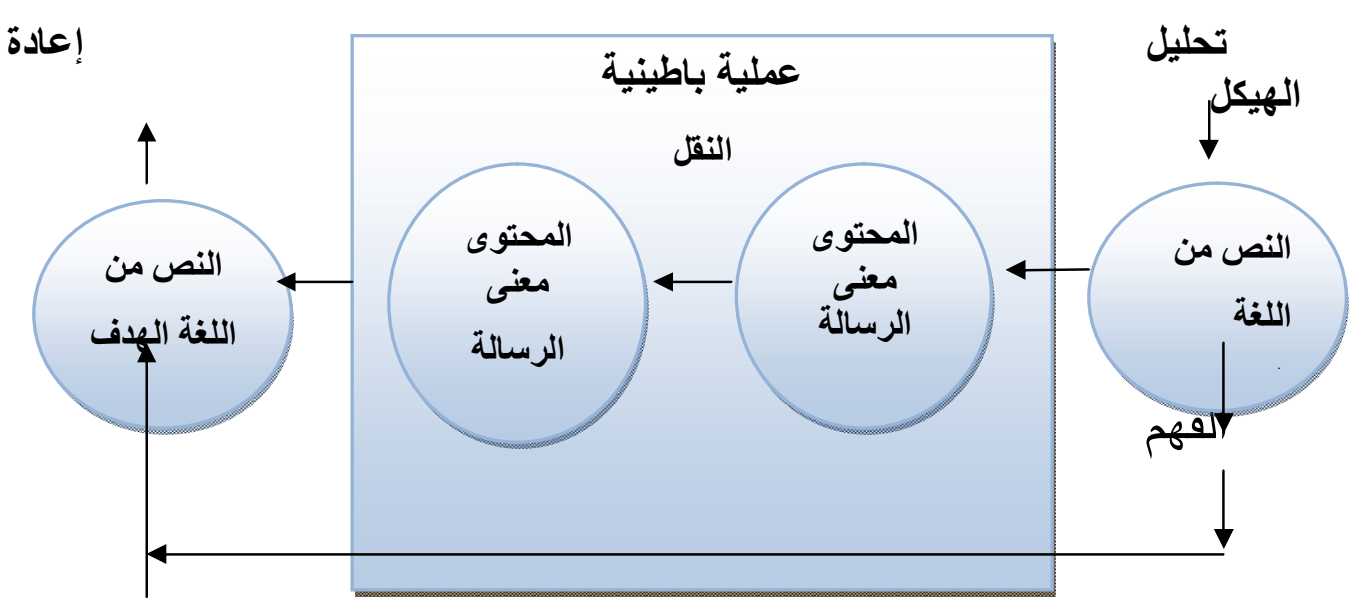

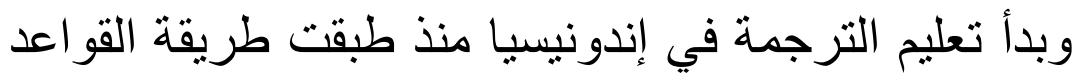

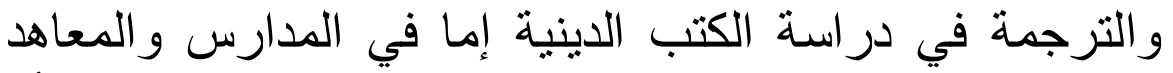

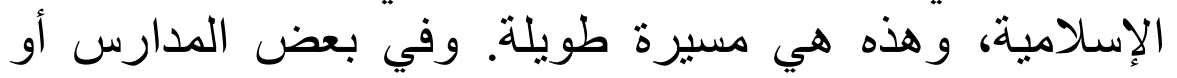


المعاهد ماز الت تطبق طريقة القواعد واترجمة في تعليم اللغة العربية، وكذلك في تعليم الترجمة.

وسوف أوضّّح تعليم الترجمة في المرحلة الجامعية كما

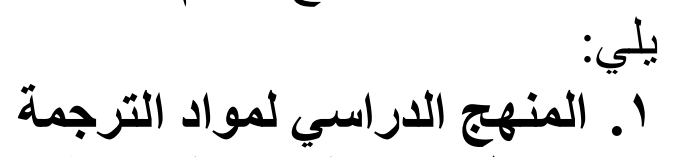

نظر ا من المنهج الدراسية في المواد الئرة الدماد الترجمة لقسم اللغة

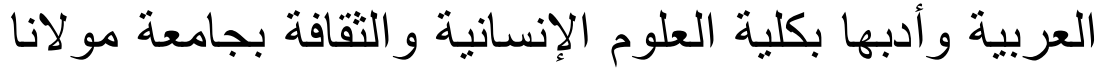

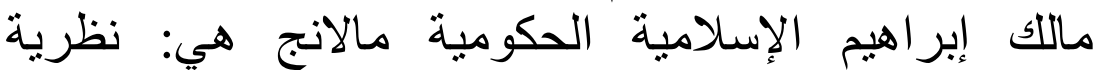

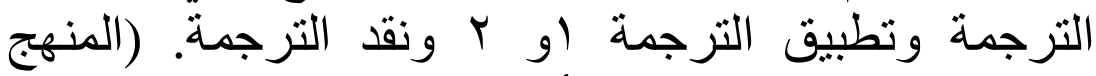
الدر اسي لقسم اللغة العربية و أبها: 9 . . . ب). r. الكفاعة المرجوة لتعليم الترجمة في المرحلة الجامعية التهاية

\begin{tabular}{|c|c|c|}
\hline الكفاءة الأساسية & الكفاعة المرجوة & المادة \\
\hline $\begin{array}{l}\text { - M emiliki kemampuan dalam } \\
\text { menerapkan prinsip dasar } \\
\text { keterampilan berbahasa. } \\
\text { - M emiliki kemampuan dalam } \\
\text { berbagai karya berbahasa } \\
\text { Arab. } \\
\text { - M emiliki kemampuan dalam } \\
\text { mengekspresikan dan } \\
\text { mengkonstruksi gagasan karya } \\
\text { berbahasa A rab dengan baik } \\
\text { dan benar. } \\
\text { - M emiliki kemampuan untuk } \\
\text { menerjemahkan karya } \\
\text { berbahasa A rab kedalam } \\
\text { bahasa tulis yang benar. }\end{array}$ & 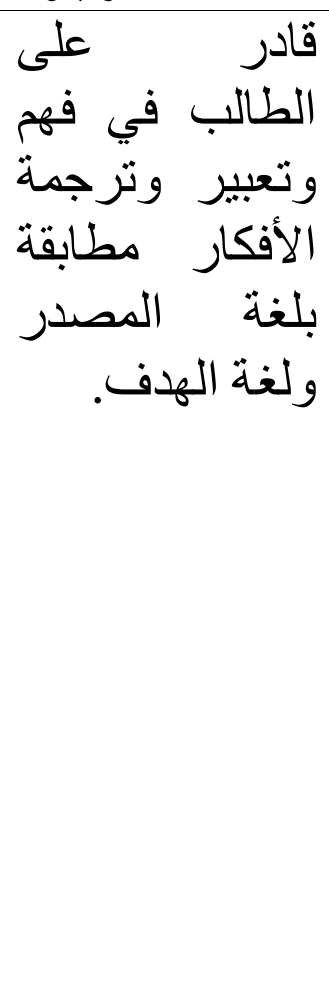 & الترجمة \\
\hline $\begin{array}{l}\text { - M ahasiswa memiliki } \\
\text { kemampuan memahami } \\
\text { prinsip- prinsip dasar }\end{array}$ & فادر الطالب في & التربيق \\
\hline
\end{tabular}




\begin{tabular}{|c|c|c|}
\hline $\begin{array}{l}\text { penerjemahan. } \\
\text { - M ahasiswa memiliki } \\
\text { kemampuan memahami } \\
\text { teknik dasar dan seni } \\
\text { menerjemah kata kerja ((fiil). } \\
\text { - M ahasiswa memiliki } \\
\text { kemampuan memahami } \\
\text { teknik dasar dan seni } \\
\text { menterjemah kata benda } \\
\text { (isim). } \\
\text { - M ahasiswa memiliki } \\
\text { kemampuan memahami } \\
\text { teknik dasar dan seni } \\
\text { menerjemah huruf. } \\
\text { - M ahasiswa memiliki } \\
\text { kemampuan memahami } \\
\text { teknik dasar dan seni } \\
\text { menterjemah ayat Al- Q ur'an. }\end{array}$ & 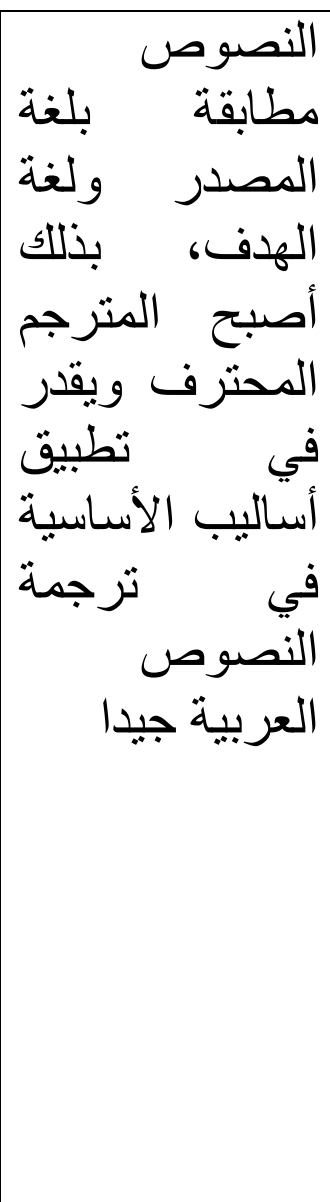 & \\
\hline $\begin{array}{l}\text { - M ahasiswa memiliki } \\
\text { kemampuan memahami } \\
\text { ragam terjemah, metode, } \\
\text { prosedur dan problem } \\
\text { penerjemahan. } \\
\text { - M ahasiswa memiliki } \\
\text { kemampuan memahami } \\
\text { teknik dasar dan seni } \\
\text { menerjemah ragam teks } \\
\text { bahasa A rab kedalam bahasa } \\
\text { Indonesia. } \\
\text { - M ahasiswa memiliki } \\
\text { kemampuan memahami }\end{array}$ & 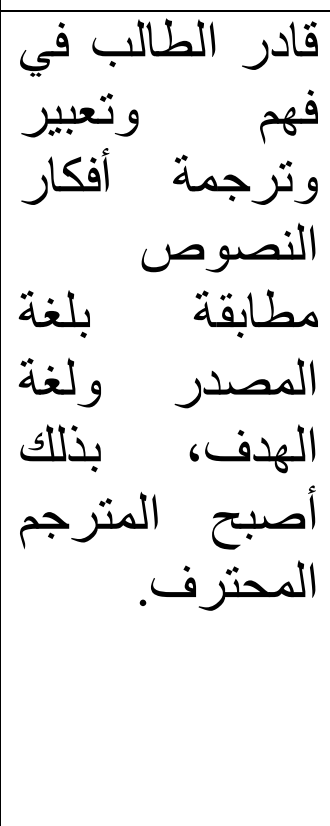 & تطبيق \\
\hline
\end{tabular}




\begin{tabular}{|l|l|l|}
\hline $\begin{array}{l}\text { teknik dasar dan seni } \\
\text { menterjemah ragam }\end{array}$ & \\
- teks/karya berdasarkan ilmu \\
dari bahasa A rab ke Bahasa \\
Indonesia.
\end{tabular}

\section{ץ. طريقة تعليم الترجمة}

(G abr, كانت طربقة تعليم الترجمة متعددة، وعند جبر (2001في إيمزير Emzir هناك طرائق متعددة هي طريقة المحاضرة وطريقة المناقشة وطربقة السعية و البصرية وطريقة التجربة وطربقة على أساس الحاسوب. (إيمزير،

$$
\text { . }(9: r \cdot r
$$

بنسبة إلى طربقة تعليم الترجمة في قسم اللغة العربية و أبها، بدأ المعلم بتقديم المعارف حول كيفية ترجمة الإسم

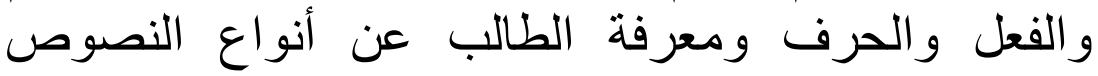
وترجمة العمل وتطبيق في ترجمة تلك النصوص من (لم)

إلى (له).

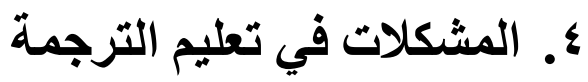

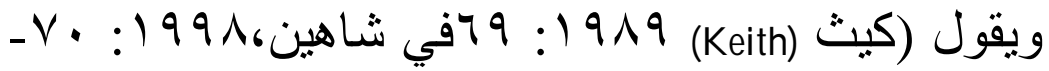

(V) ( أنه كان هنالك دائما خلاف حول القضابيا التالبة: ( ) فيما إذا كان المترجمون مو هوبين أم مصنو عين. 
Y Tيما إذا كان بالإمكان تدريب المترجمين في مؤسسات تعليمية.

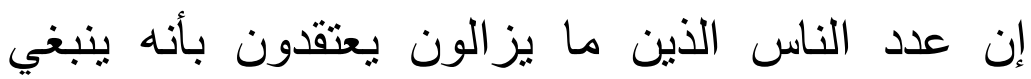

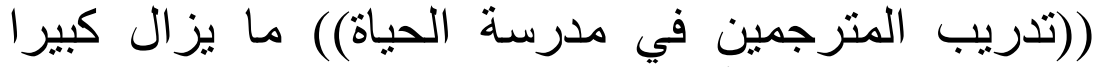

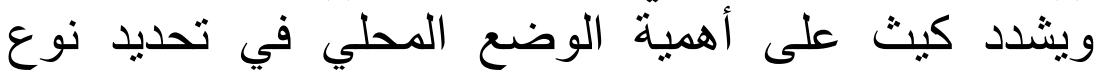

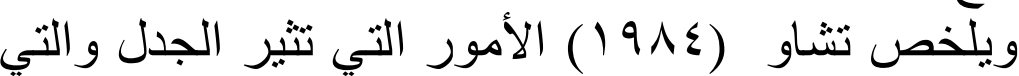

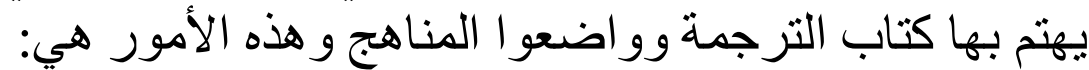

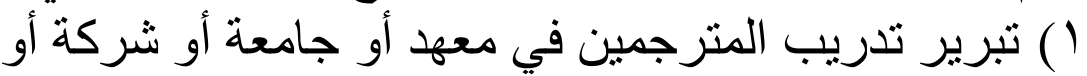
مؤسسة نشر أو قسم حكمي.

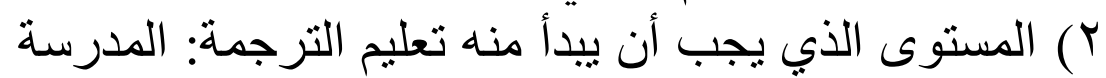
الثانوية أو الجامعة أو في الدر اسات العليا. ع) أهداف التدريب. ع) المقدرة اللغوية للمرشحين. ( ) الترجمة اللغوية للمرشحين. 7) مؤ هلات المترجمين. و أما المشكلات في تعليم الترجمة في إلتئ إندونيسيا كثيرة

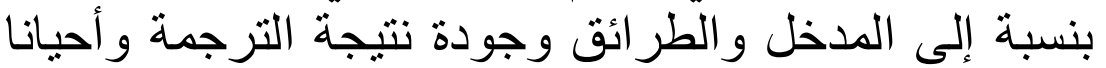

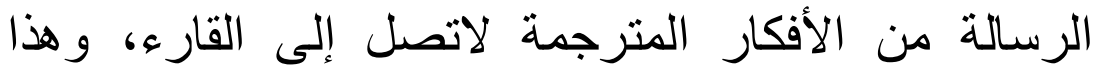

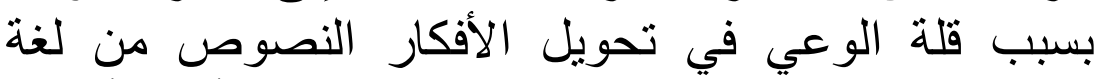
المصد إلى لغة الهدف. وكذلك مشكلة منى يجب أن أن ييدأ تعليم لئي الترجمة في إندونيسيا.

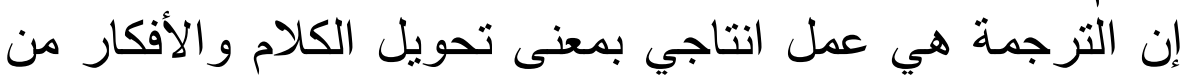

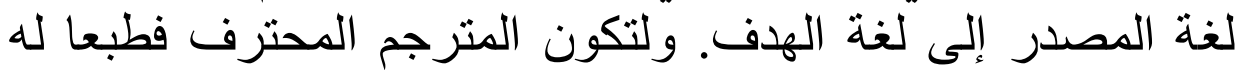

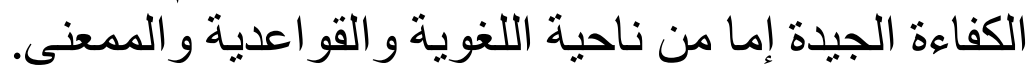

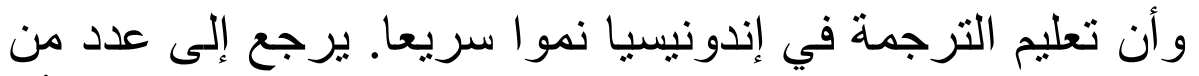
الكتب الإسلامية والعلمية المترجمة إلى اللغة الإندونيسية، رئية رغم أن الني

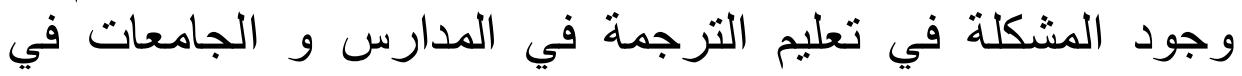
إندونيسيا. 


\section{المراجع}

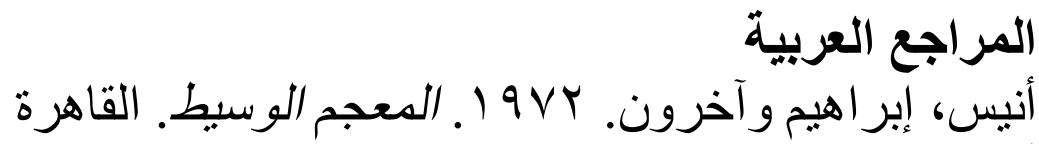

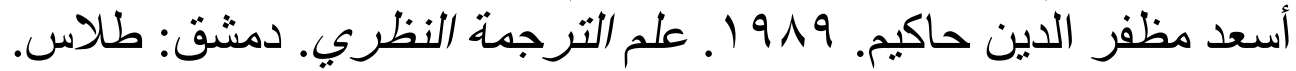
إسحق رحماني. · l · ب دراسة نقدبة فنبة حول نرجمة النصوص المادة

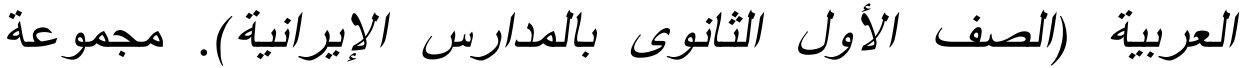
البحوث العلوم الانسانية وتحديتها ومساهمتها. مؤتمر اديا الدولى الاولى كلبة العلوم الانسانبة و الثقافة جامعة مولانا ماللك ابر اهيم الاسلامبة مؤهية

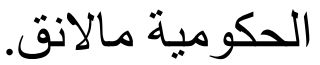

إخوان عزيزي. با ب. ب. الثرجمة: ماهبتها وكبفيتها. كتاب المؤتمر الدولي للغة العربية. تفعبل اللغة العربية كعنصر حضاري مستقبل مانيل

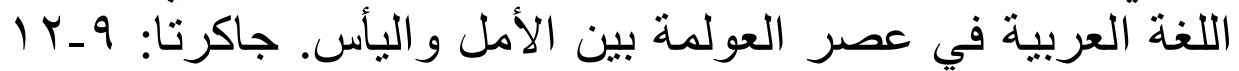

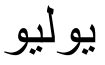
رحيمة جو لانبان وصادق إبراهمى كاورى. . 1 . ب. الترجمة الأدبية قضابا ونقدها. مجموعة البحوث العلوم الانسانية وتحديتها ومساهمتها. مؤتمر اديا الدولى كلية العلوم الانسانية و الثقافة جامعة ولهابة مو لانا مالك ابر اهيم الاسلامبة الحكومية مالانق.

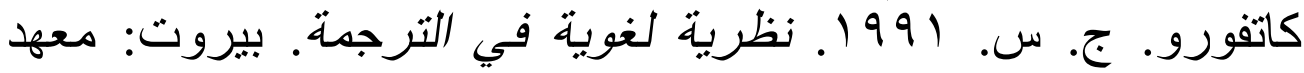
الانماط العربهي.

محمد شاهين. 9191 ا ـ نظربات الترجمة وتطبيقاتها في تدربس الترجمة من العربية إلى الانجليزبية وبالعكس. عمان: دار الثقافة. المراجع الأجنية المئه

Emzir. 2003. Pendekatan Pengajaran Terjemah. Makalah disajikan dalam Pertemuan Ilmiah Nasional Bahasa Arab (PINBA III) di Istana Wakil Presiden dan Asrama Haji Pondok Gede Jakarta, 4-6 September.

Mufid, Nur. Kaserun AS. Rahman. 2007. Buku Pintar Menerjemah (ArabIndonesia). Surabaya: Pustaka Progressif.

Murtadho, Nurul. 1999. Metafora dalam Al-Qur'an dan Penerjemahannya. Disertasi tidak diterbitkan. PPS. Universitas Indonesia.

Silabus Jurusan Bahasa dan Sastra Arab. 2009. Fakultas Humaniora dan Budaya. UIN Malang. 